\title{
Towards understanding mission to Muslims in Kenya A missio-Dei perspective
}

\section{Rebecca Jepkemei Lagat ${ }^{1}$}

\begin{abstract}
A proper understanding of mission as a concept is essential for effective mission to people of other faiths. Most theologians refer to this concept as missio Dei which entails God's Triune purpose in mission from the beginning to the end. Missio Dei is yet to find a universally acceptable definition and practice among Christians. Its nature and content remain problematic to the relevant stakeholders in mission. This article critically examines the missionary engagement to Muslims by five selected Evangelical churches in Eldoret Kenya. It investigates how and to what extent these churches implemented God's mandate in light of the missio Dei. Using data collected from oral interviews and document analysis (DA), the research shows that the churches face challenges such as a lack of concrete understanding of God's mandate for mission, internal disputes, financial constraints and the neglect of both the youth and women within the church. The conclusion indicates poor understanding and an ineffective strategy to approach Muslims. The recommendation is a new paradigm shift with a view to engaging Muslims in Eldoret in light of Gospel and in the spirit of the missio Dei.
\end{abstract}

Key Words: Christianity, Evangelical, mission, missio Dei, Muslims, Eldoret, fundamentalists

\section{Introduction}

At the core of the divine message in the Bible is God's mission - a means through which God is committed to redeem His people from eternal condemnation to eternal glorification. As part of the people's group presumed to be without the Good News of salvation, Muslims in Eldoret risk such a condemnation unless Christians deliberately seek them out. The research for this article critically examined recorded activities of five selected Evangelical churches in Eldoret Kenya carried out for 15 years $(1994-2009)$ in its mission to Muslims. The focus was on the manner and the extent to which these Evangelical churches sought to implement their missionary mandate in light of the missio Dei. The term Evangelical as employed in this article, means "being committed to the centrality of Christ, historic Christian

She is a research fellow at the University of North-West and can be contacted at omwenga.becky@ gmail.com 
orthodoxy, and the urgency to proclaim the Gospel in word and deed, calling the world to repentance and faith" (Tennent 2010:225 and Bebbington 2009 ).

The centrality of Christ is material in this case because His teachings and ministry provides the critical link for the missio Dei in the Old and New Testaments. David Bosch's definition of missio Dei provides a working definition that guides the discussion in this article. Bosch defines missio Dei as "primarily and ultimately, the work of the Triune God, Creator, Redeemer, and Sanctifier, for the sake of the world, a ministry in which the church (Israel) is privileged to participate' (Bosch 2009:392). Apparently, for various reasons, Evangelical churches in Eldoret have lost this focus on mission to people of other faiths. Most Christian churches have the desire to accept new converts into their congregations (McGavran 1980:38-43). The churches selected for this research are no exception. They show enthusiasm for mission but their implementation is found to be slow, tedious and misdirected. Evangelical churches are founded on beliefs and practices that are at variance with those of the Muslims. For example, whereas the former churches believe in the teachings and the authority of Jesus Christ as the Son of God and the Saviour of the world (Sesi et al. 2009:239-242), the latter faith groups reject such teachings and view Him as a mere prophet (Qur'an 5:75; 19:30-35). These differences form part of the external factors that impede attempts by Evangelicals to advance the mission to Muslims. This article focuses on the role of the Church as God's instrument in advancing mission to people of other faiths, particularly to the Muslims at Eldoret. Whilst there is known to be inter-faith engagement in the north-eastern and coastal parts of Kenya, limited information is on record as far as Christian commitment to Muslims in Eldoret is concerned.

\section{Defining missio Dei}

Bosch's balanced definition of missio Dei stated above comes in handy in providing a focus for this research. Bosch (2009:390-393) views mission primarily as an attribute of God, as opposed to primarily an activity of the church. God is a missionary God; therefore, mission is a movement from God to the world whereby the Son and the Spirit through the Father jointly take the initiative in mission in their Triune nature. As an instrument, the church is included in this mission, which implies that the members' participation in the movement of God presents God's love towards the lost people.

This definition of missio Dei resonates in Wright (2006:22-23), who recaps that if mission should be biblically informed and validated, then its meaning should include the church's committed participation as God's people, at God's invitation and command, in God's own mission within the history of God's world for the redemption of God's creation. Wright also distinguishes God's role from that of the 
church. God is viewed as the Owner of mission, whereas the church participates on the invitation and command of God. Moreover, the fact that Wright (2006:23) mentions the purpose of God's mission as the redemption of God's creation corresponds with Bosch's (2009:390) statement that the church is an instrument of God's love in the world.

From the statements and claims above, missio Dei can be defined as God's purposes in and out of His creation (Engelsiveken, 2003) meaning that at the creation everything made was perfect (Gen. 1:31) but sin destroyed His perfect purpose soon after. Nonetheless, in (Gen. 3:15), God's work of recreation is to be fulfilled when the New Jerusalem descends on earth (Rev. 21:2). Thus God is the One that defines His purpose of creation and recreation. God is the Initiator, Sustainer but importantly, He is the Implementer of His mission. However, since the church is the representative of God in mission (Roxborough, 2014:122), this raises the question as to the relationship between God's missio Dei, God's church (encompassing God's faithful people) and the world (encompassing people of other faiths) in the context of Eldoret. In other words, how do the Evangelical Christians in Eldoret view and consider Muslims? Is their missionary engagement to Muslims contextualised in light of the missio Dei?

\section{Contextualizing missio Dei}

The concept of missio Dei (God's mission) underpins the teachings of the Bible as far as the church's mission to people of other faiths is concerned. Historically, mission signifies the deliberate attempt of individuals, groups and churches to evangelise non-Christian societies. Missionary groups operate by acting in a Christ-like way towards people of other faiths while living beyond their boundaries, whether religious, cultural, social or other. Warneck (1987:1) defines mission as evangelism to build the church in a non-Christian world. McGavran (1983:26) views mission as carrying the Gospel across cultures, especially to people of other faiths who owe no allegiance to Jesus Christ. In other words, engaging people of other faiths or undertaking church mission is understood in terms of the missio Dei. Appreciating the role of the missio Dei in this way means to acknowledge the purpose for which the earth and all therein is given by God. Wright (2006:399) points out the premise that Yahweh, the God of Israel, owns the whole universe. The psalmist confesses, "The earth is the Lord's and everything in it, the world and all who live in it" (Ps. 24:1).

God is the Initiator of mission to people of other faiths. This would mean that He is presumably the author of all religions of the world, Islam and Muslims included? (Stetzer, 2011) .While this is debatable, the Christian Scripture depicts God as the Founder of the nation of Israel (Gen. 12:1-3), as well as of the New Testa- 
ment church. He is also confessed as the Sustainer throughout the human history (Richebacher, 2003). It thus stands to reason that since God is behind "all", then His missio Dei includes all that God created. "All" signifies the whole of creation, time and humanity from the creation onwards (Turaki, 2015). In Matthew 24:14, Jesus prophesises that the word of God shall be preached to the world as whole, as prelude to the expected second coming of Christ. This is a universal claim that defines the story of the world as a whole as a public truth (Wright, 2006:54-55). To embrace this truth is to follow a meta-narrative, a grand narrative that describes a creational beginning of all things, an interpretation of the meaning of the cosmic history in between, and an end with a regenerated creation story. Within this hermeneutically unified design the context of missio $D e i$ is set.

\section{Research objectives}

This research was guided by the following objectives:

1. Examine critically the mission to Muslims by five selected Evangelical churches in Eldoret Kenya.

2. Investigate how and to what extent these churches have sought to implement their mandate in light of the missio Dei

\subsection{Methodology}

The qualitative research method was used, seeing that it intends to construct meanings without influencing or manipulating the subject or site of inquiry. While the research drew substantially from the primary data generated by in-depth interviews with church leaders and departmental leaders, it also made use of secondary sources of information. However, there could be no document analysis to describe and interpret the church's written records because no such records were found. In its place, transcribed speeches were included (Marshal \& Rossman 1999, Bogdan and Biklen 1992). Observation comprised the gathering impressions of the surrounding world through all relevant human faculties without necessarily influencing or coercing the subjects under observation (Adler \& Adler 1998:80). The participants were asked questions relating to their church's missionary engagement to people of other faiths, and especially Muslims in Eldoret. The responses will be expounded below.

\subsection{Population and sampling techniques}

A non-probability, purposeful form of sampling (Dahlgren et al. 2004:14-16) was used to select the population, five churches that engage in missionary activities to Muslims in Eldoret Kenya. The selected churches were the Reformed Church of East Africa (RCEA), the African Inland Fellowship Church (AIFC), the Faith Baptist 


\begin{tabular}{lllll} 
Denomination & Frequency & Percentage & Member groups & Focus groups \\
\hline AIFC & 45 & $18.5 \%$ & 3 & 7 \\
FBC & 37 & $15.5 \%$ & 3 & 9 \\
ACK & 65 & $27.3 \%$ & 3 & 8 \\
PCEA & 35 & $14.7 \%$ & 3 & 5 \\
RCEA & 56 & $23.5 \%$ & 3 & 6 \\
\hline Total & $\mathbf{2 3 8}$ & $\mathbf{1 0 0 . 0}$ & $\mathbf{1 5}$ & $\mathbf{3 4}$
\end{tabular}

Table 1: Distribution of respondents by denomination

Church (FBC), the Presbyterian Church of East Africa (PCEA), and the Anglican Church of Kenya (ACK). These five churches were chosen for two reasons; firstly, they form part of the mainline churches, or churches founded by the missionaries in the early 20th century (Falk 1979:261-270). Secondly, they share common attributes such as their manner of worship and their commitment to advance missio $D e i$ to people of other faiths, including Muslims.

The target population was selected randomly from an approximate equal crosssection of the church hierarchy who are adherents of Evangelical theology. A total of 238 participants were divided into three member groups (men, women and youths) in each church and a total of 34 focus groups were used (see Table 1 below) The criterion for selection was applied at random with a view to obtaining an almost equal cross-section of adult men and women, and teenage males and females in each church. This was done to form a balanced view of the work of Evangelical theology, inter-cultural mission and the spreading of the Gospel in general.

The variation in the sample size from each church was due to differences in the church population.

\subsection{Data-collection procedure}

The oral interviews that were conducted were voice-recorded. The principle of bracketing was applied to ensure that pre-understanding the information did not influence the data. Bracketing implies that the researcher holds back ideas, presumptions, and personal understanding when listening to, interacting with, and reflecting on the stories of informants (Moustakas 1994, cited in Creswell 2007:11-13). This is done to avoid influencing the description of the phenomenon under research. To enhance reliability, field notes were recorded in a diary. The voice-recordings were monitored and notes were taken whenever technical problems arose. Data was transcribed and analysed using both qualitative and quantitative methods. 


\subsection{Study Setting}

Eldoret is a rapidly growing city in western Kenya with an estimated population of 289,380, making it Kenya's fifth largest city. Located within Eldoret are Moi University School of Medicine (Kenya's second largest medical school), Moi Teaching and Referral Hospital (MTRH), and the Academic Model Providing Access to Healthcare (AMPATH) Program, a large HIV care and treatment program. Eldoret is the administrative center of Uasin Gishu County, where $51.8 \%$ of the population lives under Kenya's poverty line, exceeding the national average of $47.2 \%$ (Sober et al, 2013). Kiswahili is commonly spoken in town but in rural areas, Kalenjin is widely spoken. Christianity and Islam have both existed in the metropolis of Eldoret, but recently, there has been increased Islamic activities including construction of mosques, health centers and madras schools along the highways.

\section{Findings and discussions}

The findings represented in Table 2 below are discussed in terms of the demographic information provided in Table 1 above. Where necessary, variations will be indicated as percentages of the distributions that were already given. Table 2 provides the findings of converts from Muslims in the respective churches during the period of research $(1994-2009)$.

\subsection{Understanding of the mission field}

The majority of the 238 participants $(90 \%)$ were of the opinion that the mission field entailed 'faraway places' where missionaries were sent to go and deliver the good news to people who had never heard about the Gospel. Of the $10 \%$ of the participants with a different view, $3 \%$ maintained the mission field was everywhere in the world, while the remaining $7 \%$ added that it include surrounding areas of one's livelihood. On the definition of the mission of the church and its involvement to the people of other faiths, over 70\% of the respondents quoted Matthew 28:18-20 (the Great Commission) as basis. In contrast, 30\% felt that the mission of the church excluded the Muslim community because they already had their own religion.

Regarding the understanding of the missio Dei, only a negligible $1 \%$ of the participants had an idea of its meaning. The rest of the participants admitted to hearing the term for the first time. One participant from the RCEA mentioned that the church bus had the words missio Dei encrypted on it, but wondered why he, as many others, did not make an effort to find out about the meaning. Other participants stated that the term missio Dei was commonly used by their theological pastors but with little explanation in their reading. The participants were also asked about the role the Godhead played in the mission of the church. As many as $72.6 \%$ of the participants pointed to Jesus the Son of God as the One in charge of mission. 


\begin{tabular}{llll} 
Denomination & Year established & Total membership & Muslim converts since 1995 \\
\hline AIFC & 1940 & 120000 & \\
FBC & 1970 s & 50000 & 2 \\
ACK & 1959 & 90000 & 0 \\
PCEA & 1947 & 100000 & 1 \\
RCEA & 1944 & 110000 & 3
\end{tabular}

Table 2: Findings of Muslim converts in the respective churches from 1994 - 2009

However, $10 \%$ of the participants indicated that mission was the work of the Holy Spirit, pointing to the fact that mission to Muslims was a difficult task. Another $10 \%$ said it was the work of God the Father and only $7.4 \%$ viewed it as the work of the Triune God.

\subsection{Reasons for engaging Muslims}

Out of the total of 238 participants, $57.6 \%$ agreed unanimously that engaging Muslims in Eldoret and Kenya in general was not only noble but also desirable and an on-going action. In contrast, $42.4 \%$ indicated that this engagement, though desirable, was slow and disjointed and hence negligible. The pro-engagement group presented four reasons to back their allegations. The reasons are explicated below.

Firstly, they cited the numerous evangelistic campaigns ('crusades') to and from Eldoret town as well as many other towns in Kenya as an indication of mission brought to Muslims. However, this is not the same view as another group of participants who stated categorically that such crusades did not target Muslims in particular, but people of other faiths in general, including back-sliding Christians.

Secondly, the engaging of Muslims was linked to the prayer activities which Evangelical Christians held daily and weekly in towns. For them this was a sign that Christians were lifted up by the Spirit to break down the barriers between Christians and Muslims and hence provide many workers and volunteers for the mission to Muslims. However, another participant from the youth-member group of the RCEA challenged this notion. According to this respondent, there was no evidence of Muslims attending the midweek prayer meetings in homes. Thus, the claim by Evangelical Christians of meeting and engaging in midweek prayers was thought to be superficial, also given the fact that no significant conversions had been recorded from home engagements, as AIFC members pointed out.

Thirdly, there was an effort from individuals who were interested in engaging Muslims in Eldoret. AIFC leaders reported having between two and five trained missionaries ministering in mission to the Muslims each year. In contrast, some 
participants who were members in the same church disclaimed the involvement of such trained missionaries who, according to them, target Muslims in other areas but not in Eldoret. Moreover, individual engagement was seen as a weakness for the church. The departments were not sensitised to work in unison with other churches in engaging Muslims in town. According to them such a problem came as a result of disputes among churches due to issues such as tribalism and nepotism.

Fourthly, the engagement of Muslims was presupposed because of what the participants termed as the Christian mandate given by Christ in Matthew 28:18-20. However, little evidence to validate these works was seen generally, which is a cause for concern. Participants seemed to agree on the need for the churches to come together soon to deliberate on these issues.

\subsection{Factors contributing to poor engagement of Muslims}

Out of the $57.6 \%$ participants who agreed that there was engagement and good reason to engage the Muslims, $66 \%$ were young people who were not involved in church leadership. Of the $33 \%$ women who agreed that there was good reason to engage Muslims, only $20 \%$ were involved in church leadership and the majority of $80 \%$ were not. Contrary to these, $42.4 \%$ of the participants doubted whether there was any form of engagements with Muslims. The doubtful participants included $75 \%$ men and $25 \%$ women.

The findings above validated the following factors for the poor engagement with Muslims in Eldoret. Firstly, it was evident from the gathered data that men comprised a large percentage of the leadership (80\%) in these churches. The statistics above indicated further that the majority of participants who discouraged the engagements with Muslims were men. Thus the church leaders evidently did not show concern for missionary engagement with Muslims. As a result, they were of the honest opinion that there was no meaningful engagement with Muslims in their missionary endeavour.

Secondly, males who formed the majority of the leadership were reported to pay little attention to inter-cultural relationships. One respondent from the $\mathrm{FBC}$ indicated that Christian males were not naturally demonstrating patience, nor paying attention to cultural details when interacting with Muslims. This was seen to be a disadvantage to engagement with Muslim believers who were reported to be strict adherents to their religion and culture. Another respondent recounted his own ordeal with a Muslim neighbour who disregarded his wife's greetings during a door-to-door visit to conduct evangelism in their area of residence. Without understanding the culture defining the relationship of women and men in public, the Christians left the exposed Muslim's house with no apology for making them feel disrespected. There also is the view that males are not patient to learn and adjust to other people's culture during mission 
work. Such action creates a bad attitude towards undertaking mission to Muslims and hence results in negative feelings and even enmity.

Thirdly, out of the 238 respondents, only 50 (21\%) reported having any form of training on engaging Muslims. From the 50 who received some form of training, 28 were women, 12 were youth and 10 were adult men. The reason for such low numbers among men in churches were seen to include: lack of personal interest for organised training and evangelism workshops, absence from seminars aimed at sensitizing Christians on Christian-Muslim relations, more involvement in other areas of church leadership, engagement in other core occupations and the situation that many churches had a smaller number of male members compared to youth and females. Generally, the low training numbers accounted for the poor engagement between Christians and Muslims in Eldoret.

Fourthly, related to the low training and lack of sensitisation was the churches' failure to come up with effective programs to reach out to Muslims. Of the five churches, only two, the FBC and AIFC, indicated that it had programs for its membership to engage Muslims. These included programs such as inter-religious debates (mihadharas) and prayer groups. The debates were seen to be ineffective because they were controversial and often confrontational. Moreover, such programs excluded female participants. However, women reported many engagements through prayer cells and one-on-one conversations with Muslims.

Internal disputes were mentioned as another factor contributing to poor engagement. Youth participants complained of the in-fighting of adults and leaders. These altercations cause division among members and lead to a lack of interest in evangelism. The participants also decried the inter-denominational differences as a cause for division among the Evangelical churches. Such divisions reportedly lead to a string of individual churches shying away from uniting with others for the common purpose of bringing mission to Muslims.

Misappropriation of funds meant for evangelism was another claim made by participants as a factor hampering engagement with Muslims. Participants expressed the need to fund the full-time evangelists who dedicate their time and lives for the service. According to another participant remuneration was required to sustain these evangelists and their families. However, funds were no longer available, as one participant pointed out, and added that the collections that were made were allegedly misappropriated by church leaders. Some purportedly used such funds for functions which they deemed more important. Funding for literature and other related costs such as transport, housing, seminars, campaigns and crusades were therefore reported to be jeopardised.

Some participants felt that the mission mandate was not given a priority because evidently, the churches considered other issues as more urgent to address. Among 
the youth groups, the participants mentioned issues such as HIV/AIDS to be of priority in their discussions, rather than Islamic issues. Reportedly, the attitude of these RCEA leaders was one of the factors leading to their synod's failure to address issues of mission among the Muslims.

\section{Other related factors regarding mission to Muslims in Eldoret, Kenya}

\subsection{Ideological differences}

Islam as a religion is both missionary and political in nature. Ousman (2004:66) alludes to the fact that Islamic movements have a dual focus of political and social gains as well as proselytism or Da'waa mission, depending on whether there is a Muslim majority in that country. The political gains were violent and had a tendency to terrorise those considered as "infidels" (Ousman 2004). This was seen as a major challenge to any religion or society coming in contact with these movements. As a result, their resurgence in Africa and Sub-Saharan Africa does not only challenge the masses but also Christianity as a whole. As a competitor, Islam challenges Christianity in areas of Da'wa (Mwakimako, 2007:291), and poses a danger in proselytizing Christians. Da'wa is the equivalence of Christian mission in Islam where Muslims engage in mission to win over non-Muslims to their faith. On its side, Christianity struggles with issues such as folk religion, corruption and hypocrisy.

Ideological differences between Islam and Christianity may hamper the mission to Muslims. The belief in the singleness of God (Tahwid) challenges the teaching of the Trinity and undoubtedly confuses both Christians who wish to evangelise Muslims, as well as those Muslims who wish to join Christianity. To be ignorant of these differences worsens the engagement. Unless there is a deliberate move to redefine these terms, the work of engaging Muslims will be difficult not only in Eldoret, but globally.

\subsection{Fear}

Fear is a factor experienced in two ways. When militant Islam propagates terror and wages war against the "infidels" who defy the Shariab law (Otenyo, 2004; Pizza, 2009; Rosenau, 2005), a global fear psychosis can develop. Fear, therefore, cannot be overlooked at any time. On the other end of the scale, Muslims who are converted to Christianity fear for their lives, on one hand the fear of rejection due to the lack of acceptance from the Christian fraternity, and on the other hand the real threat to their lives by fellow Muslims who view them as betrayers of the Islamic religion. The participants in Eldoret stated it categorically that fear made evangelizing to Muslims difficult because of the threatening persecution and the alienation of converted Muslims. 


\subsection{Cultural differences}

Culture is a central component of any religion and faith. Muslims were said to be united by their beliefs because they were defined by their cultural orientation. In Christianity, it is easier to differentiate between beliefs (faith) and culture (way of life). In Islam, however, there is a tendency to equate culture with religion and vice versa (Mwangi, 2014). Many Christians in Eldoret seemingly do not understand the way Muslims live. This ignorance can be regarded as the probable reason for their laxity in undertaking mission to Muslims. Also in this case, there are certain myths surround historical injustices between Christians and Muslims, which will be explained subsequently.

In Kenya, Islam is still being associated with and blamed for the practice of slavery. As a consequence, Muslims in Kenya are constantly put on the defensive (Kurtz, 2005). Moreover, Muslim-Christian/Christian-Muslim relations did not improve, seeing that Christians' attitudes towards Islam and Muslims had not changed to date. Accusations initially made by missionaries in their quest to dissuade indigenous communities from adhering to Islam are reiterated by individuals in positions of leadership (Fonge, 2015:6-7). Exaggerated talk both in public and on religious grounds bred contempt and enmity between the two religious groups in Kenya. All the participants agreed that there seems to be animosity between the two religious groupings, which made it difficult to reach one another.

\subsection{Political and economic factors}

Religious actions typically thrive in a peaceful and politically stable environment. Militant Islam seems to defy this order. The fundamentalist notions of Islam (according to Ousman 2004:65), are the pillars on which their political activism is based. According to this view, Islam's ultimate aspiration is the Islamization of society and state. Especially the fundamentalists will over-exert themselves to realise this goal. Christianity is presumed emphasise peace, justice and unity within society, whereas fundamental Islam operates within confusion and terror, irrespective of the definition of the term Islam, which means submission to Allah and at times defined as a way of peace (Lausanne, 2002; Odhiambo et al, 2012). Of relevance is the association of both parties with the West and East respectively. This leads to an engagement of a seemingly never-ending war. The result of such a war is a cumulative negative engagement and intolerance between the faith groups.

\section{Missiological implications and recommendations}

From the findings discussed above, several implications and recommendations can be drawn about the level of understanding and engagement demonstrated by Evangelical Christians in Eldoret Kenya. Primarily, Christians have a misconception and misunder- 
stand their role and duty as followers of Christ in missionary engagement with people of other faiths or belief systems. Even though the churches in Eldoret deliver a form of Christian evangelism to their neighbours, including the Muslims, the engagement fails to honour their God-given command as defined in the missio Dei. Ambiguously absent is the passion for the many unsaved people languishing and perishing in spiritual poverty.

Apparently, select Evangelical churches in Eldoret are not following God's mission or even engaging in the missio Dei. Either, these churches are not sensitizing both the youth and women, and as a result, there is a general lack of understanding regarding the work of the missio Dei. This can be substantiated by the lack of commitment in engaging Muslims both at personal and public levels. Additionally, this lack of understanding and commitment accounts for several actions of poor engagement through mission work. This includes the lack of proper planned strategies and efforts to engage Muslims. Thus, there are no properly set out plans of evangelism to engage Muslims deliberately. The evangelization actions do not target Muslims directly. Proper actions and action plans in spreading the Gospel to Muslims should be mapped out in Eldoret, Kenya.

The objectives above can be achieved when the following 'missional road map' is followed to concretise the missio Dei:

The various churches in Eldoret should consider and engage in meaningful dialogue with their Muslim neighbours. This calls for wisdom in organizing and executing the dialogue. The role-players involved should be well selected and chosen after careful prayer. Proceeding of such dialogues should be well documented and presented to the stakeholders, who should include: leaders from both sides, that is, Christian pastors, church elders and departmental heads on one hand, and the Imams, sheikhs and Muslim teachers on the other. All reports and recommendations put forward during and after the dialogue should be written down. Religious experts in the field of missiology should then follow up on questions and difficult subjects arising from these written 'agendas'.

Both churches and mosques should provide platforms for teaching and understanding of faith before attacking the other group's stance of faith. Love for God and humankind should define the relationship between Christians and Muslims and above all between neighbours in Eldoret. God's love as defined in (I Tim. 2:4; 2 Pet. 3:9), calls for a strategy that invites all people to be saved and also to find the fullness of God's truth. Sermons and evangelization messages should stress: God's desire goes beyond the current issues that Christians in Kenya and especially in Eldoret may be facing. It should be pointed out: God's will is that all people, including Muslims, to come to the full knowledge of Him. Overall, there is no single approach to the current response to Islam; the correct response depends on many factors. However, all responses should be effected out of love as an attribute of true believers. 
The current tension existing between the Christians and Muslims should be countered by defining the underlying problems responsible for these tensions. These include but are not limited to: the general belief and the notion that "all Muslims are terrorists", that all non-governmental organizations funded and run by Muslims harbour terrorists and that every activity organised by Muslims is suspect and should be treated so at all times. Ideological differences between the two religious groups, which has created a rift and led to mounted tension in the past, should be addressed urgently. Such tensions do not only impede cross-cultural and faith dialogues but also causes animosity amongst neighbours. Moreover, ideological divergences from Christian perspectives are grossly misunderstood whenever Christian-Muslim dialogues take place.

Christian's lack of understanding of Islam doctrine makes it extremely difficult to engage Muslims without evoking emotional clashes and confrontations. Such fears could be allayed if religious harmony and dialogue were encouraged. Christians and Muslim leaders in Kenya should be seen at the forefront diffusing tensions and fears whenever ideological differences arise. If Christians in Kenya were keen, they would realise that Islam does not necessarily employ force to spread their religion. Their simplicity of the Islamic faith and the straightforwardness of its doctrines, including its acceptance of African cultures and especially polygamy, are tolerated by many young people. This is one of the areas that church leaders need to review and appreciate.

There is a need to address the issues affecting young people dropping out of school and those who are unemployed. Strategies should include rolling out programs to teach and coach young people on launching small enterprises and business. This also means that the churches should be ready and willing to raise funds for such programs. Additionally, the leaders should provide the opportunity to the Christian members, mostly women and youths, who are willing to engage Muslims. The reason is that the leadership, consisting mostly of males, evidently is not willing to engage the Muslims themselves. Therefore, efforts to witness to the Muslims are halted at leadership level within the Evangelical Christian churches of Eldoret Kenya.

Christians in Eldoret must organise training to target the children, youth and women. Missionary experts and teachers can be sourced from across the world to disciple and mentor these special groups that they could evangelise to the Muslims. Holistic education encompasses all members of the body of Christ towards the work of salvation. Households can be organised as well to reach out to their Muslims neighbours. The Bible provides enough guidance on how to take the Gospel to the whole world. Education provides a key to spreading the good news successfully. If embraced, Christian education can win many Muslims to Christ. This is because the Kenyan education system and curriculum allow for Christian religious education. 
There is also a need for deliberate efforts by all churches in Eldoret Kenya to understand and define the Islamic objective in Africa. The way forward is to send large numbers of students to missiological institutions, in order to study the history of Islam and its expansion as well as the current trends of Islam in Africa with special emphasis on the rise of Islamic radicalization, extremism and fundamentalism in this region.

The Christian churches in Kenya in general, and evangelical churches in Eldoret in particular, should not work on their own in matters of religious freedom and liberty. They should engage the government and other religious stakeholders to monitor and interpret the activities of Muslims and Islamic expansion in the country. The allegation from a section of the youths that Islam is luring them into joining institutions of businesses and learning in exchange for allegiance to the Islam faith, should not be taken lightly, nor accepted on face value. Investigations to establish the truth about such recruitments should be a matter of concern both to the Christians and the government. This should especially be the case in the wake of AlShabaab's recruitment of the youths reported around the country. Such allegations, if corroborated, can be a channel for peaceful engagements with peace-loving Muslim leaders who oppose any act of terror and violence against all Kenyans.

\section{Conclusion}

Finally, the question remains: Can there be hope in a context where success in engagement seems to have faltered? The answer is in the affirmative, although it may require addressing and rectifying the failures highlighted in the conclusions above. To begin with, the Evangelical churches in Eldoret ought to redefine their mandate to include other faith groups and especially Muslims. A clear "thus says the Lord" should govern the attitudes and motives moving forward. Love and understanding for the true meaning and purpose of God's missio Dei and love for fellow men should form the basis of a clear mode of operation. The various components of the body of Christ should be involved, a good way is to identify and train young people who are aspiring to be missionaries. Proper mentorship programs within church institutions which make discipleship mandatory should be introduced. This forms part of a missio Dei paradigm for engaging people of other faiths in the community of Eldoret, Kenya.

\section{Bibliography}

Bebbington, D. 2009. How old is the old time religion? Scholars challenge David Bebbington in the advent of evangelicalism. Available online http://www.christianitytoday.com/ ct/2009/juneweb-only/126-12.0.html. Accessed 1 October 2017. 
Bosch, J. D.2009. Transforming mission: paradigm shifts in the theology of mission. Maryknoll, NY: Orbis.

Colaizzi, P.F. (1978) Psychological research as the phenomenologist views it. (In Lopez, K.A. \& Wills, D.G., Descriptive versus interpretive phenomenology: their contributions to nursing knowledge. Qualitative Health Research (2004), 14, 726-735).

Creswell, J.W. (2003). Research design: a qualitative, quantitative and mixed method approaches. London: Sage.

Engelsiviken, T. 2003. Missio Dei: The understanding and misunderstanding of a theological concept in the context of European churches. International Review of Mission. 93 (367), 481-497. Available online: http://www.stevethomason.net/wp-content/uploads/2013/09/Missio-Dei-The-Understanding-and-Misunderstanding-E.-Engelsvikenflattened.pdf. Accessed 26 June 2015.

Falk, P. 1979. The growth of the church in Africa: contemporary evangelical perspectives. Grand Rapids, MI: Zondervan.

Fonge, F. 2015. Conceptualizing the trajectories and proselytization of Islam in Africa. International Journal of Humanities and Social Science 5(3), 24-35. Available online: http:// www.ijhssnet.com/journals/Nol_5_No_3_March_2015/4.pdf. Accessed 07 August 2015.

Kurtz, R. Lester. 2005. Gullen's paradox: Combining commitment and tolerance. Islam, using religion at the cost of innocent lives. Available online: http://ejournals.ebsco.com. nwulib.nwu.ac.za/Direct.asp? Accessed 26 June 2015.

Lausanne, W. J. 2002. (Ed.) Islam: historical, social and political perspectives. Berlin: Walter de Gruypter.

McGavran, A. D.1980. Understanding church growth. Grand Rapids, MI: Eerdmans.

McGavran, D.A. 1983. What is mission? (In Glasser, A.F. \& McGvran. Contemporary theologies of mission. Grand Rapids, MI: Baker).

Mwangi, M. Isaack. 2014. The role of communication and the media in inter-religious conflict between Christians and Muslims in Kenya. Available online: http://erepository. uonbi.ac.ke/bitstream/handle/11295/77768/Mwangi. Accessed 26 June 2015.

Odhiambo, E.O.S., K. Onkware, J. Kassily, L.T. Maito, W. A. Oboka, J. W. \& Wakhungu, O. M. 2012. Kenya's pre-emptive and preventive incursion against Alshaabab in the light of international law. Journal of Defense Resource Management, 3 (1:4), 27-36.

Otenyo, E.E. 2004. New Terrorism: toward an explanation of cases in Kenya. African Security Review 13 (3), 75-84 Essay. Available online: https://www.issafrica.org/pubs/ ASR/13No3/EOtenyo.pdf Accessed 27/January 2016.

Ousman, A. (2004) The potential of Islamist terrorism in Sub-Saharian Africa. International Journal of Politics, Culture and society, 18 (1/2), 65-105. Available online: http://www.jstor.org/stable/20112134. Accessed 08 July 2014.

Pizza A. J. 2009. Is Islamist terrorism more dangerous? An empirical study of group ideology, organization, and goal structure. Terrorism and Political Violence, 21 (1), 64.

Richebacher, W. 2003. Missio Dei: the basis of mission theology of a wrong path? International Review of Mission 92 (367), 588-605. Available online: http://onlinelibrary. wiley.com.nwulib.nwu.ac.za/doi/10.1111/j.1758-6631.2003.tb00431.x/epdf. Accessed 26 June 2015. 
Rosenau. W.2005. Al-Qaeda recruitment trends in Kenya and Tanzania. Studies in Conflict and Terrorism. 28 (1), 1-10. Available: http://www.tandfonline.com/doi/ pdf/10.1080/10576100590524357. Accessed 18 August 2015.

Roxborough, J. 2014. Missiology after 'mission?' International of Bulletin of Missionary Research 38 (3), 120-124. Available online: http://eds.b.ebscohost.com.nwulib. nwu.ac.za/ehost/pdfviewer/pdfviewer?vid=5\&sid=e5d98bc0-257b-4eef-b06ec1379ed3c6f3\%40sessionmgr113\&hid=126. Accessed 26 June 2015.

Sessi, Mutuku et al. 2009. African missiology: contribution of contemporary thought. Nairobi, Kenya: Uzima.

Sober, R., et al.2013. Social and economic characteristics of street youth by gender and level of street involvement in Eldoret, Kenya. PLoS ONE 9(5), 1-9. Available online: http://journals.plos.org/plosone/article/file?id=10.1371/journal. pone.0097587\&type=printable. Accessed 1 October 2017 .

Stetzer, ED. 2011. Christianity today: Proselytizing in a Multi-Faith World. Available online: http:/www.christianitytoday.com/edstetzer/2011/april/christianity-today-proselytizingin-multi-faith-world.html. Accessed 1 October 2017.

Tennent, C. T.2010. Invitation to world missions: a Trinitarian missiology for the twenty-first Century. Kregel Academic \& Professional.

Turaki, Y. 2015. Theism and creation: foundations for morality and ethics. Potchefstroom: North-West University, May (Lecture).

Wright, J. H. C. 2006. The mission of God: unlocking the Bible's grand narrative. Westmont, IL: Inter-Varsity Press. 